\title{
Cash boost for US science
}

\section{Researchers in line for \$13-billion windfall.}

After getting their first glimpse of the massive financial stimulus bill last week, US researchers are scrambling to work out how to get some of the billions of dollars proposed for science and technology into their laboratories.

On 15 January, the House of Representatives released details of its proposed US $\$ 825$-billion economic stimulus bill. Along with other spending initiatives and a raft of tax cuts, the blueprint includes new, one-off funding for federal research and development that totals more than $\$ 13$ billion.

Among the big winners is the National Science Foundation (NSF), which would receive an additional $\$ 3$ billion - half of its annual budget - of which $\$ 2$ billion would go directly to research grants. The National Institutes of Health (NIH) would receive $\$ 3.5$ billion, of which $\$ 1.5$ billion would be for research at NIH centres over two years; $\$ 1.5$ billion for building grants at university research facilities; and $\$ 500$ million for construction on the NIH campus in Bethesda, Maryland. The
Department of Energy's Office of Science would receive $\$ 2$ billion, which includes $\$ 400$ million to kick-start the Advanced Research Project Agency-Energy, which is meant to fund highrisk research in innovative energy ideas.

As expected, other clean-energy initiatives also reaped billions of dollars. Some $\$ 4.5$ billion would go to efforts to develop a smart electricity grid; $\$ 8$ billion would go to loan guarantees for renewable-energy technologies (see page 362 ); and $\$ 2.4$ billion would go to projects in carbon capture and sequestration at fossil-fuel-burning plants.

Many research advocates had pushed Congress and the incoming administration of Barack Obama for such investments, and predictably applauded the proposal (see Nature 457, 240-241; 2009).

Robert Berdahl, president of the Association of American Universities in Washington DC, said the bill represents a solid endorsement of the scientific community's argument that investing in research and education provides

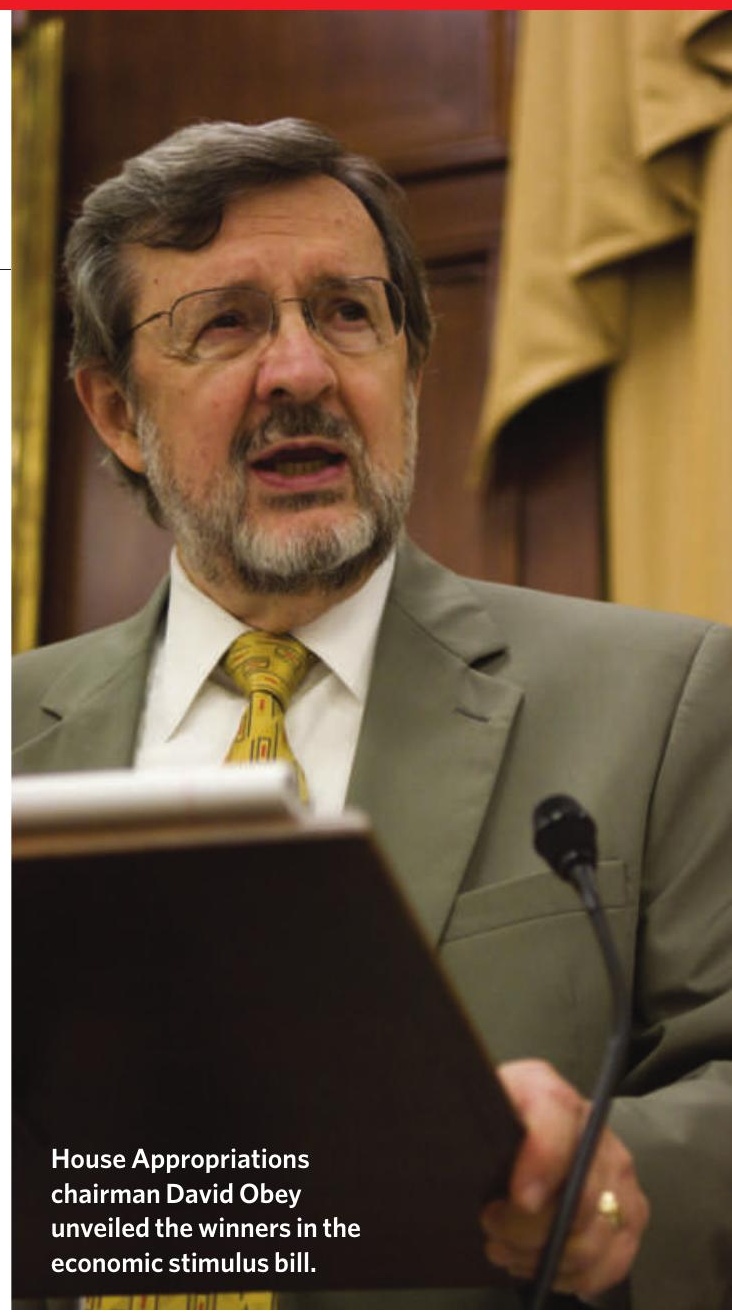

\section{Ebola outbreak has experts rooting for answers}

When the Ebola Reston virus was discovered in pigs in the Philippines last year, it marked the virus's first known foray outside primates, and raised fears of a potential threat to human health.

Last week, a joint mission of 22 international health and veterinary experts returned from investigating the outbreak with more questions than answers about the virus's pathology and epidemiology.

The Ebola Reston virus was first discovered, in 1989, in crab-eating macaques imported to the United States from the Philippines. Since then, the virus has killed most infected monkeys, yet had no effect on the 25 people that it infected - unlike three of the four other strains of Ebola, which kill between $25 \%$ and $90 \%$ of the humans they infect.

Because few people come into close contact with primates in the Philippines, the risk of catching Ebola Reston in this way is relatively low. By contrast, the appearance of the virus in an important livestock species was unexpected and worrying, says Pierre Rollin, an Ebola expert at the US Centers for Disease Control and Prevention (CDC) in Atlanta, Georgia, who was part of the mission to the Philippines. "We never thought that pigs could be infected," he says.

Once inside the pig, it may be possible for the virus to mutate into a version that is deadly to humans, as the avian influenza virus is thought to have done. "And we still don't know what it might do to someone who is immunocompromised by HIV or by drugs," Rollin adds.

But there seems to be little threat to human health from the current form of the

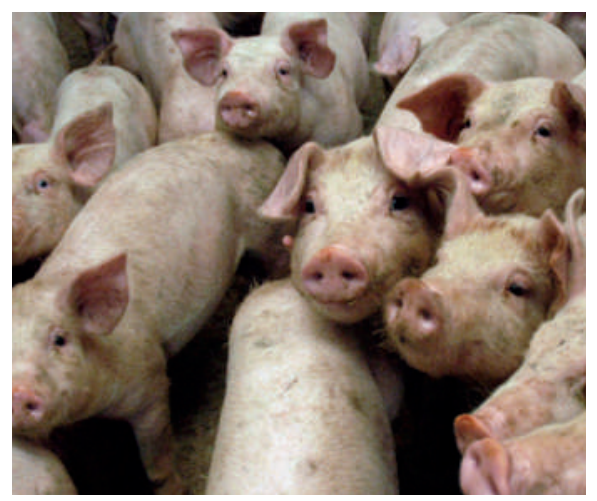

Is an Ebola-virus subtype killing pigs? virus. It is destroyed by cooking, and there is no evidence of symptoms in pig handlers, who will soon be tested to find out if they have developed antibodies to the virus.

The investigation into the Ebola Reston infections began after farmers in the Philippines reported high mortality rates in their pigs in 2008. In September, samples from 28 dead pigs were sent to the Plum Island Animal Disease Center in New York, where researchers found evidence of the porcine reproductive and respiratory syndrome virus, also known as blue-ear pig disease, which has seen many outbreaks in Asia in recent years. But in six of the samples they also found Ebola Reston. This virulent, biosafety-level-4 pathogen requires special laboratory facilities, so the pig samples were rushed to the CDC labs in Atlanta for further analysis.

Despite the presence of other diseases in the samples - including swine fever, and the porcine circovirus type II - Rollin thinks that Ebola Reston is to blame for the pigs' deaths because histological samples showed that the virus had pervaded the spleen, similar to its mode of attack in 
jobs while laying the foundation for a cleaner, more competitive economy. The trick, he says, will be getting the bill through Congress and then sustaining funding into the future.

"We hope that this gets built into the base and that it is essentially front-loading some of the increases that are planned for 2010 and beyond," says Berdahl. Obama is scheduled to present his proposed budget for fiscal year 2010 in early February.

But some have questioned whether the one-time infusion of cash will matter much to agencies whose budgets have flatlined or been lower than expected in recent years. Elias Zerhouni, former director of the $\mathrm{NIH}$, says the stimulus package does not focus enough on sustaining scientists, concentrating instead on the facilities that house them. The current proposal "is too timid and not strategic enough in addressing the long term", he says. "It's short-term wise but long-term ineffective."

Democratic congressional leaders, spearheaded by House Speaker Nancy Pelosi of California, developed the bill in consultation with Obama's transition team. Although the legislation is sure to change as it moves through the House and the Senate, the fact that it has the tacit approval of both Pelosi and Obama means that it is likely to survive in some form. Republicans, however, were not consulted.

Most of the stimulus spending would extend over two years, although money for peer-reviewed grants must be awarded within 120 days to ensure it is spent quickly. That could mean that agencies use the money to fund peer-reviewed grants that previously scored highly but were not funded because of a lack of money at the time. At the NSF, individual directorates are likely to be allowed to determine how they will spend the \$2-billion windfall. Other chunks have been designated for specific programmes: $\$ 400$ million, for instance, will go to the major research equipment and facilities programme, which includes large projects that must be approved by the National Science Board. Another \$500 million will go to instrumentation, including modernization and retrofitting.

At NASA, the $\$ 400$ million targeted for the science office includes $\$ 250$ million to accelerate Earth-sciences projects recommended in a recent prioritization survey by the National
Academies. Among other things, that would pay for a climate sensor measuring total solar irradiance to be put back on the next generation of US weather satellites; it had previously been removed to save money.

Bart Gordon (Democrat, Tennessee), chairman of the House Science Committee, called the bill a long-delayed down payment on the American Competitiveness Initiative, which seeks to boost research and education in mathematics, engineering and the physical sciences.

Neal Lane, a professor at Rice University in Houston, Texas, and a former science adviser to President Bill Clinton, says agencies such as the NSF and the Department of Energy will probably be able to absorb and spend the additional funding quickly, in part because they have been planning for increased funding under the competitiveness initiative. The NSF in particular has been faced with a backlog of requests and peerreviewed proposals for facilities and construction of major research equipment. "Those seem like reasonable places to make a quick and early investment," he says. "The researchers out there could actually spend a lot of money wisely and quickly if it were made available to them." Jeff Tollefson; additional reporting by Meredith Wadman and Rich Monastersky. monkeys. Further pathology tests are due to begin in spring at the Australian Animal Health Laboratory in Geelong, Victoria.

The infected pigs came from several farms on the island of Luzon, and on 13 January, health officials collected blood and tissue samples from hundreds of apparently healthy pigs there. Although Rollin does not expect to find the virus itself in these samples, the pigs may carry antibodies that should indicate an approximate mortality rate associated with exposure.

Rollin suspects that, as is the case with monkeys, the infections resulted from contact with a reservoir of the virus, rather than spreading from animal to animal. In 2005, outbreaks of human Ebola in Gabon and the Republic of the Congo were traced back to colonies of bats (E. M. Leroy et al. Nature 438, 575-576; 2005). "It's almost certainly the case [in the Philippines]," says Rollin.

The virus is likely to be spread by bat droppings falling into the pigs' feed, and the threat of infection could be reduced by moving fruit trees, where the bats roost, away from pig farms, or by putting roofs on pig enclosures. "We can't exterminate it, we just have to learn how to avoid it," says Rollin. David Cyranoski

\section{GRAPHIC DETAIL Prices plummet on carbon market}

The price of European Union (EU) allowances for carbon dioxide emissions has reached an all-time low, hit by falling oil and gas prices, and expectations that economic recession will lead to reduced energy demand.

Under the EU's mandatory emission trading system - set up in 2005 and still by far the largest such scheme in the world - power plants and other $\mathrm{CO}_{2}$-intensive industries can buy emission allowances that allow them to exceed their government-allocated $\mathrm{CO}_{2}$ caps. In 2008, the equivalent of almost 5 billion tonnes of $\mathrm{CO}_{2}$ was traded on the global market, an 83\% rise on 2007.

At close of trading on

19 January, allowances to emit one extra tonne of $\mathrm{CO}_{2}$ in 2009 were selling at just $€ 11.65$ (US\$15.32) on European exchanges that

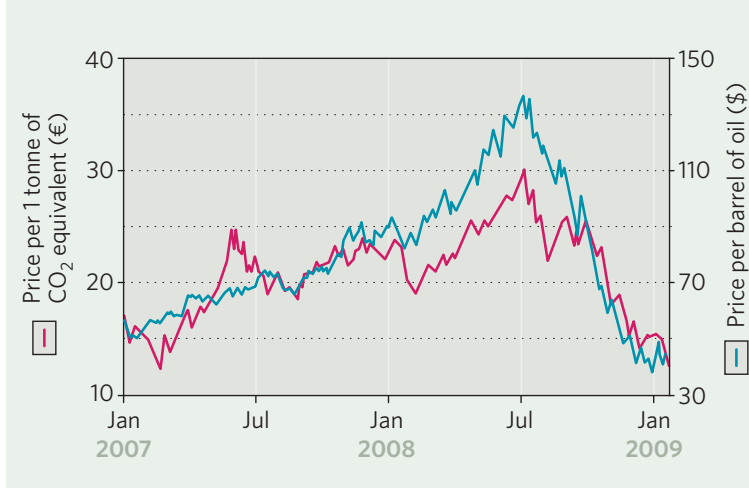

trade carbon, such as the European Energy Exchange (EEX) in Leipzig, Germany (see graph). The price of allowances saw a recent peak of above $€ 30$ in July 2008, but falling oil and gas prices have encouraged electricity generators to switch from burning coal to cleaner natural gas, reducing demand for emission allowances
Given the dire economic outlook, analysts believe that it will be difficult to stop the market's negative trend in the next few months.

The EU's emission trading system is due to be reformed in 2013 to reduce the amount of free allowances handed out to companies (see Nature 456, 847; 2008).

Quirin Schiermeier 